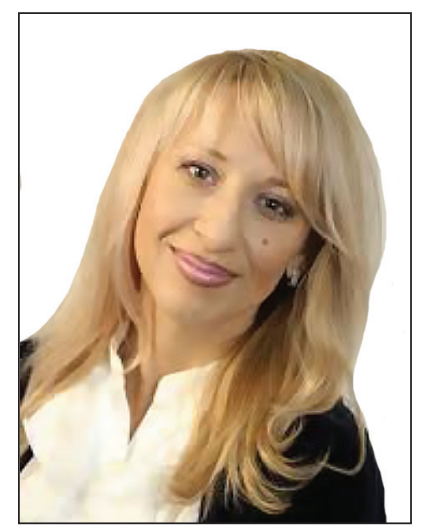

Tragniuk Olesia Yanivna, PhD in Law, Associate Professor

of the International Law Department, Yaroslav Mudryi National Law University,

Ukraine, Kharkiv

e-mail:otrag@ukr.net

ORCID 0000-0002-4505-8105

doi: 10.21564/2414-990x.143.148861

UDC 341.215.2: 061.1 €C:355.45

\title{
LEGAL AND ORGANIZATIONAL INSTRUMENTS OF THE EU COMMON DEFENSE POLICY IMPLEMENTATION AT THE PRESENT STAGE
}

The article deals with the problems of legal and institutional support for the implementation of the Common Defense Policy of the EU in current circumstances. The peculiarities of legal regulation of this policy and certain organizational and legal forms of its provision have been determined. It has been established that the legal instrument that provides the implementation of the General Defense Policy, which is an integral part of the Common Foreign and Security Policy of the EU, has its own features related to the nature of the cooperation of the member states in this area. It is about not so significant, in comparison with economic sphere, restriction by the member states of their sovereign rights in determination of questions of external safety and defense. The consequence of this is the adoption of acts that are predominantly «soft» by their character.

The EU initiatives in the field of strengthening the Union's defense capabilities in the context of the implementation of the Global Strategy for the European Union's Foreign and Security Policy have been analyzed as well as the international legal framework for cooperation between the EU and NATO with regard to ensuring common defense and security objectives, and also the legal nature of the European Union's acts in the field of the Common Defense Policy has been determined.

Keywords: European Union; Global Strategy for the European Union's Foreign and Security Policy; Common Defense Policy of the European Union; Common Foreign and Security Policy of the European Union; European Defense Action Plan Document; PESCO.

Tрагнюк О. Я., кандидат юридических наук, доцент кафедры международного права, Национальный юридический университет имени Ярослава Мудрого, Украина, г. Харьков.

e-mail : otrag@ukr.net ; ORCID 0000-0002-4505-8105

Правовые и организационные инструменты реализации Общей внешней оборонной политики ЕС на современном этапе

Рассматривается проблемы правового и институционального обеспечения реализации Общей оборонной политики ЕС в современных условиях. Определены особенности правового регулирования этой политики и отдельные организащионно-правовые формы ее обеспечения. Установлено, что правовой инструментарий, обеспечивающий реализащию Общей оборонной политики, 
которая является неотьемлемой частью Общей внешней политики и политики безопасности ЕС, имеет свои особенности, связанные с природой сотрудничества государств-членов в этой сфере. Речь идет о не столь значительном, в сравнении с экономической сферой, ограничении государствами-иленами своих суверенных прав в определении вопросов внешней безопасности и оборонь. Следствием чего является принятие актов, имеющих преимущественно «мягкий характер».

Ключевые слова: Европейский Союз; Глобальная стратегия ЕС в сфере внешней политики и политики безопасности; общая политика обороны ЕС; общая внешняя политика и политика безопасности ЕС; План действий в сфере европейской обороны; PESCO.

Problem statement. One of the most sensitive in terms of limiting the sovereign rights of the Member States of the European Union is the EU defense policy. It is precisely the defense and security issues, which are traditionally considered to be the exclusive competence of the state, have always been and remain the most controversial in the European Union. The achievement of harmonization of the positions of the states in this area is traditionally reached in the course of difficult negotiations, which, as a rule, reflect the different perceptions of states about the EU's relations with other countries and organizations. However, the existence of common threats faced by EU countries in recent years has encouraged them to find the best mutually beneficial forms of cooperation in the field of security and defense, which simultaneously respond both to the common and individual expectations of the member states of the Union. Therefore, the study of legal regulation of various formats of cooperation between the member states of the Union within the framework of a Common Defense Policy and the definition of the nature of acts adopted to achieve the objectives of this policy is relevant.

Recent research and publications analysis. Issues related to the coverage of the features of a Common Defense and Security Policy are mainly focused in political and sociological research, taking into account the specificity of relations between EU Member States in this area. Certain issues of the legal regulation of the Common Defense Policy of the EU at the present stage are highlighted in the works of such Ukrainian and foreign scholars as P. Belesa, Y. Bityak, I. Gorodysky, I. Grebenyuk, O. Davydenko, G. Zavoritnya, L. Zinyak, I. Kochev, I. Kuznetsova, O. Poshedin, V. Ruda, L. Falaleeva, I. Fedyk, I. Yakoviuk, Karen Devine, Klaus Carsten Pedersen, Tom Dyson, Theodore Konstadinides, Vasilis Margaras. Consequently, there is a need for further thorough studies on the legal and organizational tools for the development of the Common Defense and Security Policy of the EU in the context of its continuous advancement and modernization.

The purpose of the article is to identify the features of legal regulation of the implementation of the EU Common Defense Policy in the context of its evolution taking into account the challenges facing the European Union, as well as to study of organizational forms through which the objectives of this policy are achieved.

Presentation of the main material. The European Union is not only the largest economic partner of Ukraine, but also its foreign policy, in particular, on defense and security issues, is an important benchmark for the formation of a defense policy of 
our country ${ }^{1}$. That is why the analysis of integration processes in the EU in the field of defense remains relevant, both from a theoretical and a practical point of view.

Title II "Political Dialogue and Reform, Political Association, Cooperation and Convergence in the Field of Foreign and Security Police" of the Association Agreement between Ukraine and the EU, which is the main document that regulates the relations of our country with the integration entity, envisages strengthening of political dialogue and cooperation between the EU and Ukraine taking into account the gradual convergence in the sphere of the Common Foreign and Security Policy and the Common Security and Defense Policy. In particular, cooperation should be aimed at enhancing the political association, increasing the efficiency and level of approximation in the field of politics and security; promoting international stability and security on the basis of effective multilateralism; strengthening cooperation and dialogue on international security and crisis management, particularly to respond to global and regional challenges and key threats; enhancing result-oriented and practical cooperation for peace, security and stability on the European continent [1]. Although these provisions do not create clear legal obligations between the parties, they nevertheless urge Ukraine to improve its own mechanisms of legal regulation of defense and security issues and to find the most optimal forms of cooperation with the EU member states and the Union itself.

Today the EU's Common Defense Policy, which was introduced in 1999 as a part of a common EU Foreign and Security policy, the main provisions of which are reflected in the Treaty on European Union (Lisbon Treaty), is focused on the provision the EU with its own military capabilities for defense purposes, as well as for peacekeeping operations beyond its borders [2], and on the consolidating the principle of collective security of all EU member states. The Treaty on European Union states that member states provide the common European security initiatives with their defense capabilities, resources, armaments, and military units that are at a high level of development [13].

The history of the implementation of the EU's common defense policy relates to the formation and use of civilian military missions. Since 2003, when the first missions under the flag of the Union were formed, there were thirty four EU missions on the three continents for the purpose of security assistance. The European Union is currently implementing six military and ten civilian missions. Within the framework of the European External Action Service (EEAS) ${ }^{2}$ there is a permanent

\footnotetext{
${ }^{1}$ The European defense experience is useful for our state in terms of ensuring the territorial integrity and sovereignty of Ukraine and counteracting Russian aggression. Details: Poshedin, O.I. (2017). Nove zhyttia Spilnoi polityky bezpeky ta oborony Yevropeiskoho Soiuzu: oriientyry dlia Ukrainy. Visnyk NADU pry Prezydentovi Ukrainy (Seriia «Derzhavne upravlinnia»), 2, 48-54 [in Ukrainian].

2 The EEAS is an EU body, a unique institution created after the enactment of the Treaty of Lisbon on December 1, 2009. The EEAS assumed its duties on December 1, 2010 and is currently acting as the Ministry of Foreign Affairs and the diplomatic corps at the level of the European Union, implementing the Common Foreign and Security Policy and the external representation of the EU in other areas. The EU Military Staff that is responsible for the Common Security and Defense Policy, is also one of the departments of this service.
} 
structure - the Civilian Planning and Conduct Capability (CPCC). Also, according to the decision of the Council in June, 2017, the Military Planning and Conduct Capability (MPCC) was established within the EEAS military unit (management), which is mandated to manage all military non-governmental missions (currently there are 3 training missions in Central Africa, Mali and Somalia). In order to enhance synergy with planning and conduct of civilian missions, the Council also decided to establish a Joint Coordination Group for the support of civilian and military experts to share the experience and support practical civil-military cooperation.

The EU's activities in the area of implementing the Common Security and Defense Policy are rather diverse: from direct military engagement on land and at sea to the organization and conduction of training activities for local security forces, as well as the involvement of civilian experts, for example, in the field of good governance and rule of law practices. For better coordination and cooperation on the ground, the first single command center for the EU military training missions, currently being held in Mali, Somalia and the Central African Republic, was created.

The EU's current defense policy is shaped by both the internal (NATO's dominant role) and external (conflicts in the Middle East, Eastern Europe, aggressive Russian politics) factors. The latter, conversely, led to the approval of the new EU Global Strategy «Shared Vision, Common Action: A Stronger Europe», EUGS [3]. One of the main objectives of this document is to obtain a "strategic autonomy" of the Union in security issues [4]. The five priorities of the EU's external action were defined in the Strategy. They are:

1) security and defense enhancement;

2 ) investing in the stability of states and societies in the east and south;

3 ) development of the integrated approach to conflicts and crises;

4) promotion and support of the common regional order;

5) strengthening global governance based on international law.

The document focuses on a number of important issues, in particular on the expectations of partners of the more important role of the EU as a "global security provider" (p. 3), the need to strengthen the European Union's contribution to the security of the region and the world (p. 5), to bear more responsibility for the development of events in the world (p. 18). It is stated that the members of the European Union will have enough weight and potential to provide their own security and make a significant contribution to the world only by joining their forces ${ }^{2}$ (p. 16). The intention of the European Union "to create a powerful European defense

The EEAS manages the EU's foreign policy and cooperates with the European Commission on issues of their shared competence.

The EEAS is unique and independent from the EU institutions body, formed by merging the departments of external affairs of the European Council and the European Commission. In this case, the EEAS is completely independent of them and has its own budget.

${ }^{1}$ At the same time, it is noted that cooperation with NATO will deepen, and the US will remain a key partner in the "broader security agenda" (p. 37).

2 "Only the combined weight of a true union has the potential to deliver security, prosperity and democracy to its citizens and make a positive difference in the world" (p. 16 of the Global Strategy). 
industry" is also mentioned in the document (p. 11). Obviously, the implementation of the relevant plans will require significant increase in defense spending from the EU member states, since it will have to cope with the backlog that has arisen in the decades of underfunding of the security sector [14]. Thus, the Member States should increase defense expense and "build on security and defense potential" in order to protect Europe (p. 44). Specific targets for gaining such capacity will be identified later in the sectoral strategy. The Global Strategy only mentions in general terms that it is necessary to invest in intelligence development, drones and satellite surveillance, better border control, reinforcement of cyber defense capabilities, as well as the "full-spectrum land, air, space and maritime capabilities, including strategic enablers" (p. 45). It is noted about the need to increase the mutual compatibility of the troops of the European Union through training, to resolve "procedural, financial and political obstacles which prevent the deployment of the Battlegroups" of the European Union" (p. 47). It also mentioned about the intention of the European Union "to create a powerful European defense industry" (p. 11) [3].

The European Union adopted a package of security and defense measures ${ }^{1}$ in order to implement the Global Strategy (EU Global Strategy Implementation Plan on Security and Defense, 14.11.2016 [5]), which consists of three main elements: new political goals and ambitious objectives for Europeans to take on greater responsibility for their own security and defense; new financial instruments to help Member States and the European defense industry to strengthen their defense capability ("Defense Action Plan Document"2 [6]); and a number of specific measures for the development of the EU-NATO Joint Declaration, which defines the scope of cooperation $^{3}$. All these three elements together form a comprehensive package of measures aimed at strengthening the security of the Union and its citizens ${ }^{4}$.

\footnotetext{
${ }^{1}$ In fact, these measures are based on three strategic priorities: 1) the ability to respond to external conflicts and crises, if they arise; 2) the ability to use the potential of partners; 3) the ability to protect the European Union and its citizens through external actions. This requires enhanced cooperation between the EU member states in developing defense capabilities, improving the structures and procedures for crisis management in the EU, and strengthening cooperation with international partners, in particular NATO.

2 The European Defense Action Plan was approved by the European Commission on 30.11.2016. The plan provides for the creation of the European Defense Fund and other actions to help Member States to intensify their research and spend more effectively on common defense capabilities, thus contributing to the development of a competitive and innovative defense industrial base and the contribution of countries to strengthening the security of European citizens. The plan focuses on three main goals: increasing the cost-effectiveness of defense; strengthening of defense cooperation; building a stronger industry.

${ }^{3}$ 6.12.2016 The Council of the European Union and foreign ministers of NATO countries have simultaneously approved a common list of proposals for EU-NATO cooperation. This follows from the Joint Declaration signed by the EU leaders and NATO Secretary General in July 2016. The list of proposals covers 42 specific activities for implementation in several areas of cooperation. EU co-operation, therefore, goes to a new level when sharing common challenges is more important than ever.

${ }^{4}$ At the same time, achieving the objectives of the Plan requires enhanced cooperation between the EU member states in the development of defense capabilities, improving the structures and procedures for crisis management in the EU, and strengthening cooperation with international partners, in particular NATO.
} 
To achieve these goals, the EU needs to maintain an integrated approach to security and defense issues. To solve security problems, diplomatic, humanitarian, trade and other instruments need to be mobilized, except for purely security and defense tools. The EU must also ensure coordination between internal and external instruments, since the internal and external security frontiers are becoming increasingly blurred.

Among the specific instruments, provided particularly by the Plan, the creation of the European Defense Fund to support investment in common research and common development of defense technique and technology accords special importance ${ }^{1}$. The Plan also provides support for small and medium-sized enterprises, start-ups, second-tier companies and other defense industry suppliers as well as the strengthening of the EU's single defense market through the application of the Directive on the coordination of procedures for the award of certain works contracts, supply contracts and service contracts by contracting authorities or entities in the fields of defense and security [7] and the Directive on transfers [8] that facilitate cross-border procurement in the field of defense, support the development of sectoral standards and promote the contribution of sectoral policies, such as the EU Space Programs, to the overall priorities in the field of guardianship and defense. In addition, the Plan is aimed at improving the single market of defense.

Among the initiatives aimed at achieving the objectives of the Plan, it is worth noting the proposal of the EU Commission, supported by the European Parliament and the EU Council on the adoption of the Regulation on the implementation of the European Military Development Program [9]. The aim of this document is to the competitiveness and innovative capabilities of the European Union defense industry [9].

It should be noted that cooperation between the EU member states in the field of defense is provided at a modern stage with a very wide range of means. Among them, those previously stipulated in the Constituent Treaties, and received a new sound, in particular Permanent Structured Cooperation (PESCO) ${ }^{2}$ [10]. And new ones, such as the Coordinated Annual Review on Defense (CARD) [11], which will

\footnotetext{
${ }^{1}$ The European Defence Fund will boost the EU's excellence and efficiency in defence equipment and technology by supporting the whole production chain: research, prototype development, and acquisition. To achieve this, the Fund has two strands with different legal and funding structures (or "windows") which are complementary and are being gradually deployed:

- research ("research window"): the EU will offer direct funding (grants) for research in innovative defence products and technologies, fully financed from the EU budget;

- development and acquisition («capability window»): Member States will pool financial contributions to jointly develop and acquire key defense capabilities. The EU will offer co-financing from the EU budget to incentivise cooperation and leverage national financing.

${ }^{2}$ More details about PESCO: Barabash, Yu.H., Tragniuk, O.Ia. Pravove rehuliuvannia postiinoho strukturnoho spivrobitnytstva u sferi bezpeky ta oborono (PESCO) yak dodatkovoho mekhanizmu spivpratsi derzhav-chleniv YeS u vidpovidnii sferi. Yevroatlantychna intehratsiia Ukrainy: svidomyi oybir modeli bezpeky: zb. nauk. st. za materialamy nauk.-prakt. konf., (Kharkiv, 3 lystop. 2017 r.): u 2 ch. / redkol.: A. P. Hetman, I. V. Yakoviuk, S.M. Melnyk ta in. European Integration: Conscious Choice of Security Model Conference. Kharkiv. Part. 1, 10-17 [in Ukrainian].
} 
help States share their defense spending plans, in order to identify possible deficiencies and, most importantly, to ensure coordination in the financing of defense spending and benefit from the scale of joint activities.

It was also previously said about the special management that was created within the European External Relations Service to ensure the use of EU civil and military missions abroad.

At the same time, all initiatives and measures are not applied separately. They are part of a coherent EU mechanism involving all relevant European Union institutions and bodies, including the European Defense Agency (EDA), as well as the strong commitment and action of Member States to strengthen joint planning, development, procurement and defense operations.

Simultaneously the EU is taking specific measures to enhance resilience, for example, by improving its ability to realize, analyze and solve hybrid threats. All these objectives are achieved through The European Centre of Excellence for Countering Hybrid Threats or the European Security and Defence College (ESDC), which launched a cyber-platform to enhance cyber defense capabilities in Europe.

As already mentioned, the cooperation with NATO on the formation and implementing the common defense policy has been and remains extremely important for the European Union. Both organizations faced unprecedented challenges in the South and East. 22 of the 28 EU Member States are also members of NATO. Against this backdrop, on July 8, 2016, the President of the European Council and the President of the European Commission, together with the NATO Secretary General, signed a Joint Declaration in Warsaw to give a new impetus and new essence to the strategic NATO-EU partnership. It led to a significant increase in cooperation in all appropriate areas.

As can be seen, most of the documents adopted by the Union in the field of defense are examples of "soft law". And this is not surprising, since the issues of security and defense have affected and continue to affect spheres, which is vulnerable in terms of sovereignty [16]. Their implementation is based, first of all, on the goodwill of Member States and other subjects of law.

To sum up, it must be recalled that the intensification of the implementation of the common defense policy of the EU is due to the fact that the security environment of the European Union is becoming increasingly complex, and the threats do not cease to grow. The purpose of the Union has been and remains the provision of safety of its citizens in an unstable world. At the same time, the problem of the balance between the need to establish guarantees of defense capabilities of the Union and the sovereignty of Member States remains relevant. As a result, most security and defense acts are of a primarily political nature and supplement regulation at the national level. Simultaneously, despite the large-scale measures in the area of enhancing defense and security in the EU, these documents do not stipulate the creation of the European Army. 


\section{References:}

1. Uhoda pro asotsiatsiiu mizh Ukrainoiu, z odnoho boku, ta Yevropeiskym Soiuzom, Yevropeiskym spivtovarystvom $\mathrm{z}$ atomnoi enerhii i yikhnimy derzhavamychlenamy, z druhoho boku, vid 27 chervnia 2014 r. URL: http://zakon4.rada.gov.ua/laws/show/984_011/paran2820\#n2820.

2. Treaty of Lisbon amending the Treaty of European Union and the Treaty establishing the European Community. Official Journal of the European Union. Series C. 2007. Vol. 50. № 306. 271 p.

3. Shared Vision, Common Action: A Stronger Europe. A Global Strategy for the European Union's Foreign And Security Policy. URL: https://europa.eu/globalstrategy/sites/globalstrategy/ files/regions/files/eugs_review_web.pdf.

4. Rezultaty ekspertnoho opytuvannia «Hlobalna stratehiia YeS: Mistse, rol i vklad Ukrainy». URL: http://www.kas.de/wf/doc/kas_48665-1522-13-30.pdf?170424165403 [in Ukrainian].

5. EU Global Strategy Implementation Plan on Security and Defence, 17 November 2016. URL: https://eeas.europa.eu/sites/eeas/files/eugs_implementation_plan_st14392.en16_0.pdf.

6. Communication from the Commission to the European Parliament, the European Council, Council, the European Economic and Social Committee and the Committee of the Regions European: “Defence Action Plan Document” Brussels, 30.11.2016// COM(2016) 950 final. URL: http://eur-lex. europa.eu/legal-content/EN/TXT/?qid=1495096766575\&uri=CELEX:52016DC0950.

7. Directive 2009/81/EC of the European Parliament and of the Council on the coordination of procedures for the award of certain works contracts, supply contracts and service contracts by contracting authorities or entities in the fields of defence and security. Official Journal, L 216, 20.8.2009. p. 76 .

8. Directive 2009/43/EC of the European Parliament and of the Council, simplifying terms and conditions of transfers of defence-related products within the Community. Official Journal, L 146, 10.6.2009. p. 1.

9. Proposal for a Regulation of the European Parliament and of the Council establishing the European Defence Industrial Development Programme aiming at supporting the competitiveness and innovative capacity of the EU defence industry// COM(2017) 294 final, 2017/0125 (COD). URL: https://ec.europa.eu/info/law/better-regulation/initiatives/com-2017-294_en.

10. Permanent Structured Cooperation - PESCO Deepening Defence Cooperation among EU Member States. URL: https://eeas.europa.eu/sites/eeas/files/pesco_factsheet_19-10-2017_1.pdf.

11. Coordinated Annual Review on Defence (CARD) Factsheet // European External Action Service [BE]. URL: https://eeas.europa.eu/headquarters/headquarters-Homepage/36453/coordinated-annual-review-defence-card en.

12. Barabash, Yu.H., Tragniuk, O.Ia. Pravove rehuliuvannia postiinoho strukturnoho spivrobitnytstva u sferi bezpeky ta oborono (PESCO) yak dodatkovoho mekhanizmu spivpratsi derzhav-chleniv YeS u vidpovidnii sferi. Yevroatlantychna intehratsiia Ukrainy: soidomyi vybir modeli bezpeky: zb. nauk. st. za materialamy nauk.-prakt. konf., (Kharkiv, 3 lystop. 2017 r.): u 2 ch. / redkol.: A. P. Hetman, I. V. Yakoviuk, S.M. Melnyk ta in. European Integration: Conscious Choice of Security Model Conference. Kharkiv. Part. 1, 10-17 [in Ukrainian].

13. Horodyskyi, I. (2014). Pravovi zasady spivrobitnytstva mizh Ukrainoiu ta Yevropeiskym Soiuzom vidpovidno do Uhody pro Asotsiatsiiu. Visnyk Lvivskoho universytetu. Seriia mizhnarodni vidnosyny. Issue 36. Part 2, 74-81 [in Ukrainian]..

14. Nova Stratehiia YeS dlia zovnishnoi i bezpekovoi polityky: prahnennia «stratehichnoi avtonomnosti» ta dystantsiiuvannia vid problem skhidnoi yevropy. International Weekly, № 12 (01.07.201615.07.2016). Instytut zovnishnoi polityky Dyplomatychnoi akademii Ukrainy pry MZS Ukrainy. URL: http://fpri.kiev.ua/?p=22619 [in Ukrainian].

15. Poshedin, O.I. (2017). Nove zhyttia Spilnoi polityky bezpeky ta oborony Yevropeiskoho Soiuzu: oriientyry dlia Ukrainy. Visnyk NADU pry Prezydentovi Ukrainy (Seriia «Derzhavne upravlinnia»), 2, 48-54 [in Ukrainian].

16. Yakoviuk, I.V. (2014). Pravovi osnovy yevropeiskoi intehratsii ta yii vplyv na derzhavnopravovyi rozvytok Ukrainyю. Extended abstract of candidate's thesis. Kharkiv [in Ukrainian]. 
Tрагнюк О. Я., кандидат юридичних наук, доцент кафедри міжнародного права, Національний юридичний університет імені Ярослава Мудрого, Україна, м. Харків.

e-mail : otrag@ukr.net ; ORCID 0000-0002-4505-8105

Правові та організаційні інструменти реалізації Спільної зовнішньої оборонної політики ЄC на сучасному етапі

Розглянуто проблеми правового та інституційного забезпечення реалізації Спільної оборонної політики Європейського Союзу в сучасних умовах, зокрема у зв'язку з посиленням нестабільності у світі, наявністю низки внутрішніх проблем та значної кількості зовнішніх загроз. Визначено особливості правового регулювання цієї політики та окремі організаційно-правові форми ї забезпечення. Проаналізовано ініціативи ЄС у сфері посилення обороноздатності Союзу у світлі реалізації Глобальної стратегї ЄС у сфері зовнішньої політики та політики безпеки, міжнародно-правовий формат співпращі ЄС та НАТО щодо забезпечення спільних оборонних та безпекових цілей, визначено правову природу актів Свропейського Союзу у сфері Спільної оборонної політики.

Встановлено, що правовий інструментарій, який забезпечує реалізацію Спільної оборонної політики, котра є невід'ємною частиною Спільної зовнішньої політики і політики безпеки $\epsilon C$, має свої особливості, пов'язані з природою співпраці держав-членів у цій сфері. Йдеться про не настільки значне, в порівнянні з економічною сферою, обмеження державами-членами Європейського Союзу своїх суверенних прав у визначенні питань зовнішньої безпеки і оборони. Наслідком чого є прийняття актів, що мають переважно «м'який характер», що у свою чергу забезпечує гнучкість у прийнятті спільних рішень та одночасний захист національних інтересів держав-членів СС. Спещифіка співпраці держав-членів СС у сфері оборони та безпеки визначається також постійним пошуком оптимальних моделей ї̈ реалізації через використання передусім міжурядових методів.

Також наголошується, що, не дивлячись на широкомасштабність заходів у сфері посилення обороноздатності та безпеки у ЄС, документи, прийняті у відповідній сфері за останні роки, не передбачають створення європейської армії. Однак це жодним чином не впливає на таку можливість, оскільки це передбачено в Установчих договорах Європейського Союзу.

Ключові слова: Європейський Союз; Глобальна стратегія ЄС у сфері зовнішньої політики і політики безпеки; Спільна політика оборони СС; Спільна зовнішня політика і політика безпеки ЄC; План дій у сфері європейської оборони; PESCO.

Надійшла до редколегї 13.11.2018 р. 